\title{
GRADE III CORONARY ARTERY PERFORATION FOLLOWING PCI AND UNUSUAL STENT GRAFT DELIVERY SYSTEM
}

Miodrag Sreckovic, Nikola Jagic, Vladimir Miloradovic, Mladen Tasic, Dusan Nikolic

Clinical Center Kragujevac, Clinic for Cardiology, Interventional Cardiology department, Zmaj Jovina 30, 34000 Kragujevac, Serbia

\section{PERFORACIJA KORONARNE ARTERIJE TIP III TOKOM PCI REŠENA NEUOBIČAJENIM PLASIRANJEM STENT GRAFTA

\section{ABSTRACT}

Coronary perforations are rare but vicious complications of PCI procedures. Ellis type III coronary artery perforation represents the most severe form and demands an urgent solution. It is often necessary to perform pericardiocentesis and utilizise multiple interventional techniques to seal the perforation. Polytetrafluoroethylene (PTFE)-covered stent implantation has become one of the most frequently used percutaneous solutions, but disadvantages of this intervention are its high profile and low device flexibility. In our case, we attempted to improve the deliverability of the PTFE stent graft alone by mounting it on a bare metal stent used as a stent graft carrier.

Key words: PTFE stent, coronary artery perforation, pericardiocentesis, cardiac tamponade, coronary disease, intraoperative complications, angioplasty

\section{SAŽETAK}

Koronarne perforacije su retke ali izuzetno neugodne komlikacije perkutanih intervencija. Perforacije koronarnh arterija trećeg stepena po Elisu predstvaljaju najozbiljniju formu perforacija i zahtevaju hitno zbrinjavanje. Često je neophodno uraditi perikardiocentezu $i$ primeniti brojne interventne tehnike kako bismo rešili perforaciju. Stentovi prekriveni politetrafluoroetilenom(PTFE) postali su jedno od najčešće korišćenih perkutanih rešenja, ali su njihove mane visoki profil i slaba fleksibilnost. U našem slučaju, pokušali smo da poboljšamo plasiranje PTFE stenta montiranjem na metalni stent, koji smo iskoristili kao nosač.

Ključne reči: PTFE stent, perforacija koronarne arterije, perikardiocenteza, srčana tamponada, koronarna bolest, intraoperativne komplikacije, angioplastika

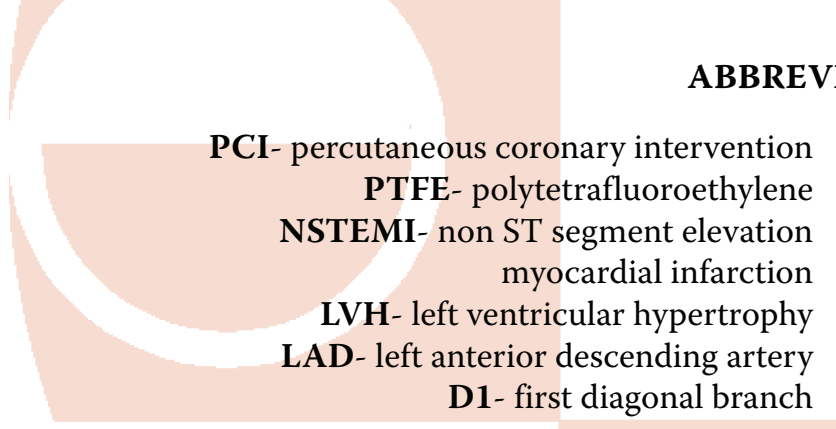

\section{ABBREVIATIONS}

S1- first septal branch

RCA- right coronary artery

SC- semi compliant balloon

DES-drug eluting stent

BMS-bare metal stent

CPR- cardiopulmonary resuscitation

CABG- coronary artery bypass graft

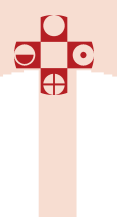

A 68 year old female was admitted to the cath lab due to complaints of postinfarction angina. She suffered an anterior NSTEMI 5 months prior to presentation. Her risk factors for cardiovascular disease were as follows: hypertension, diabetes, dyslipidemia, and a history of smoking. An electrocardiogram showed sinus rhythm, with a rate of $75 \mathrm{bpm}$, as well as

signs of LVH and a reduced R in V2. Echocardiography revealed a reduced ejection fraction - $40 \%$ and anterior wall hypokinesia. Angiography was performed, showing that the LAD was diffusely atherosclerotic and calcified, with tight stenosis approaching $90 \%$ of the vessel lumen immediately after the D1 and S1 branches (Figure1). 


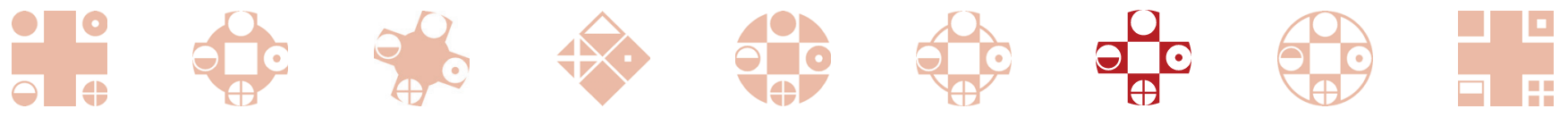

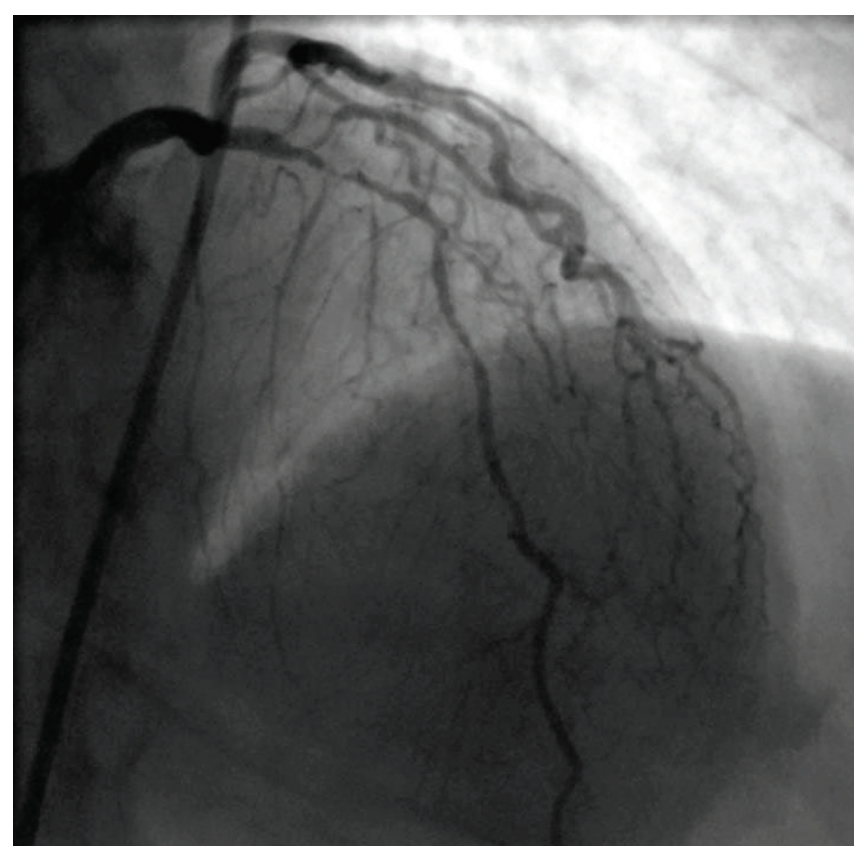

Figure 1.

The RCA provides collaterals to the LAD. The initial operator decided to perform an ad hoc PCI of the LAD. The lesion was accessed with an SC balloon with dimensions of $2.0 \times 20 \mathrm{~mm}$, using pressure up to $12 \mathrm{~atm}$. Quantitative coronary analysis assessed the artery diameter as beingapproximately $2.5 \mathrm{~mm}$, but the operator decided to

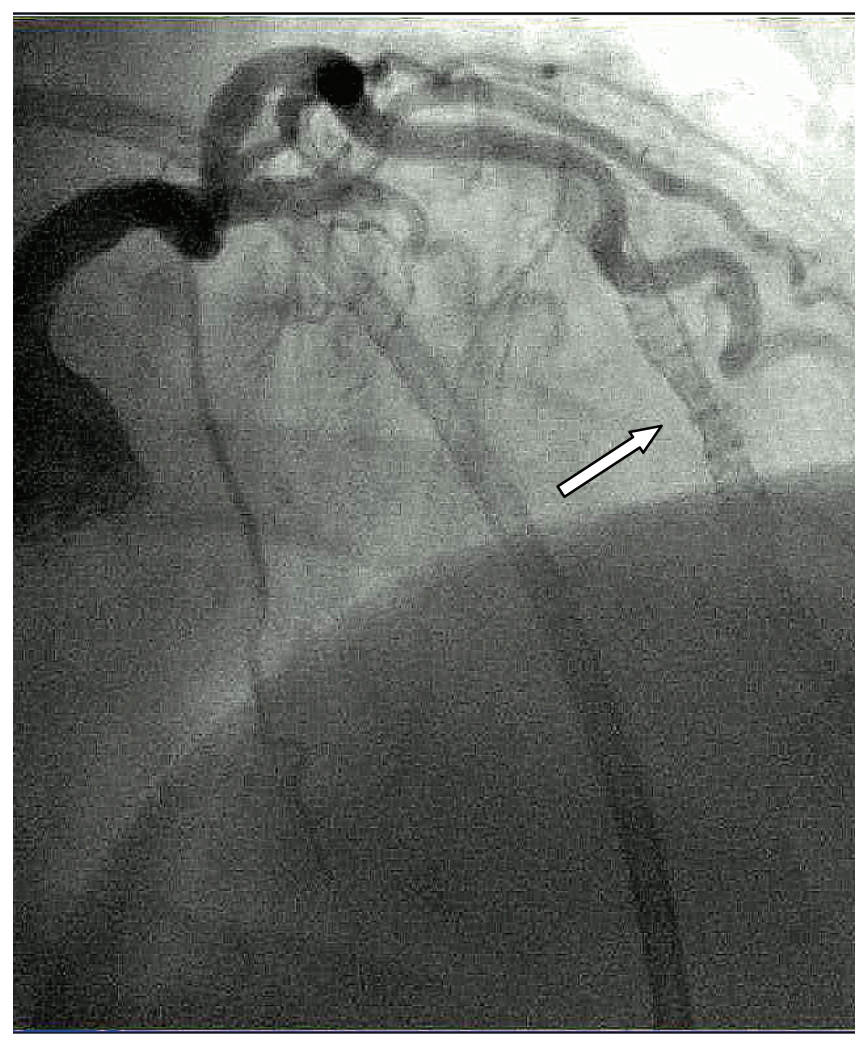

Figure 3. The white arrow points to inadequate expansion in the distal part of the polytetrafluoroethylene (PTFE) Jostent.

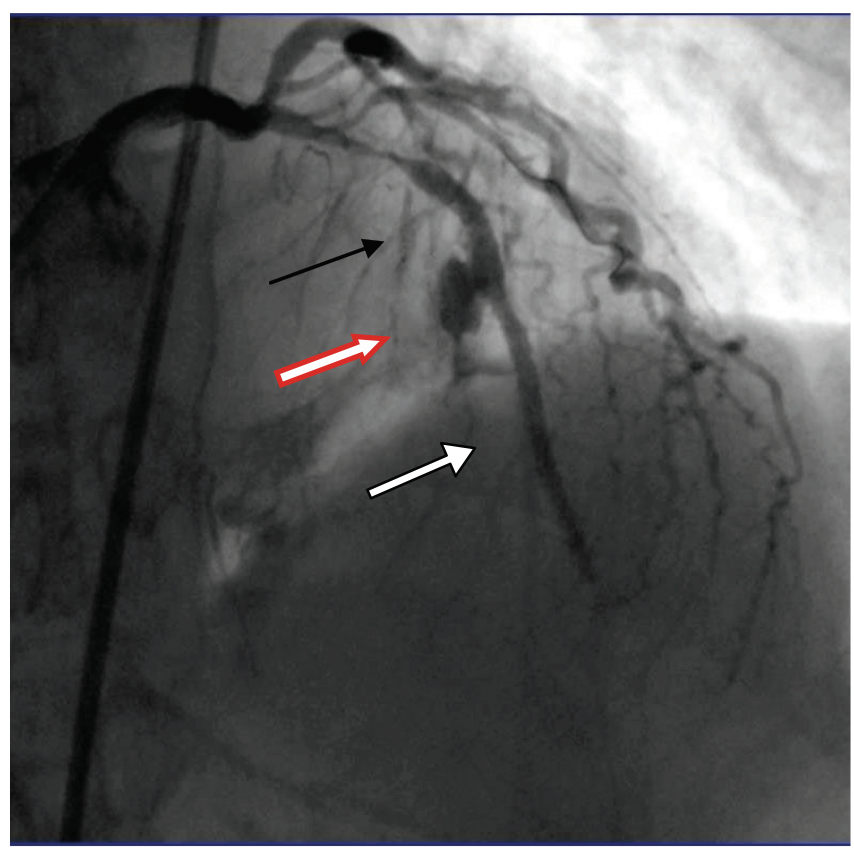

Figure 2. The white arrow indicates the position of the distal stent ( $\mathrm{Si}$ rolimus $3.0 \times 33 \mathrm{~mm}$ ), and the black arrow points to the proximal stent (Zotarolimus $3.5 \times 26 \mathrm{~mm}$ ). The red arrow points to frank contrast streaming into the pericardium.

implant a Sirolimus DES with dimensions of $3.0 \times 33 \mathrm{~mm}$, at a pressure of $14 \mathrm{~atm}$, distally. Next, a Zotarolimus DES with dimensions of $3.5 \times 26 \mathrm{~mm}$, at $16 \mathrm{~atm}$, was placed proximally, but overlapped the distal device. Immediately following stent deployment, frank contrast was noted streaming into the pericardial space, representing an Ellis grade III perforation at the distal aspect of the stent (Figure 2).

The stent balloon was immediately re-inflated to seal the leak. The operator was afraid mayof losing the stent graft when trying to place it over a proximal unexpanded stent on heavily calcified tissue. We did not have a premounted PTFE stent, so we used a bare metal stent (BMS), Flexmaster F1, (Abbott Vascular Laboratories, Redwood City, California), with dimensions of $3.5 \times 26 \mathrm{~mm}$, as a stent graft delivery system. The idea was to increase friction between the stent graft and the carrier. We manually modified and pressed the stent graft onto the BMS carrier to reduce the chances of losing the stent when crossing the heavily calcified, long lesion. The stent balloon was inflated throughout the preparation of the PTFE stent. After balloon disinflation, respiratory arrest occurred, and CPR was performed. A pericardial drain was immediately inserted, and $450 \mathrm{ml}$ of haemorrhagic fluid was evacuated. After haemodynamic stability was established, we implanted the stent graft mounted on the BMS used as its delivery system, opening it with a high pressure of 18 atm. Despite this elevated pressure, inadequate expansion in the distal portion of the $2.5 \times 19 \mathrm{~mm}$ polytetrafluoroethylene (PTFE) Jostent, to which we applied manual shaping, was observed (Figure 3). 
Stent thrombosis eventually occurred, and the remainder of the procedure was clinically uneventful, with no signs of further pericardial leakage. The patient was haemodynamically stable, as only a mild rise of cardiospecific enzymes was observed. A control echo was performed the next day, following the pericardial drain removal. The patient was discharged 3 days after the procedure.

\section{DISCUSSION}

Ellis et al. defined grade III coronary perforation as extravasation of blood through a frank perforation $(\geq 1 \mathrm{~mm}$ ) or into an anatomic cavity chamber on coronary angiography ${ }^{1}$. Previous studies reported that the incidence of grade I to III coronary perforations ranges from $0.1 \%$ to $3.0 \%^{2,3}$. In 2011, Rasha Al-Lamee et al. conducted a study focused only on grade III coronary perforations, and they reported that this remains rare, with an incidence of $0.23 \%{ }^{4}$. Additionally, in this study, the superiority of covered stent implantation over prolonged balloon inflation in reaching haemostasis was shown, and multiple methods of treatment were required in an attempt to achieve haemostasis in $39.3 \%{ }^{4}$ of patients. Grade III is the most dangerous form of perforation, associated with rates of cardiac tamponade as high as $40 \%$, and the need for emergency CABG is reportedly between $20 \%$ and $40 \%{ }^{5,6}$. In our case, we did not manage to achieve adequate haemostasis by prolonged balloon inflation; therefore, prompt implantation of a PTFE stent, along with a pericardial drain, was required to resolve this iatrogenic complication.

\section{CONCLUSION}

This approach is proposed as an alternative technique that may be used in cases where other treatment options for coronary perforation are either unavailable or are potentially not successful. BMS was successful as a stent car- rier in our case, but a disadvantage of utilizing this technique is stent malposition due to forced manual shaping, as well as consecutive stent thrombosis. Pericardial drainage is mandatory to resolve threatening haemodynamic instability, and should be performed before stent implantation. Although this grade of perforation remains rare, interventional cardiologists should be aware of the risk factors and have the necessary skills to perform multiple methods of treatment.

\section{REFERENCES}

1. Ellis S.G., Ajluni S., Arnold A.Z. Increased coronary perforation in the new device era. Incidence, classification, management, and outcome.Circulation.90 1994:2725-2730.

2. Gruberg L., Pinnow E., Flood R. Incidence, management, and outcome of coronary artery perforation during percutaneous coronary intervention. Am J Cardiol.86 2000:680-682. A8.

3. Ramana R.K., Arab D., Joyal D. Coronary artery perforation during percutaneous coronary intervention: incidence and outcomes in the new interventional era. J Invasive Cardiol.17 2005:603-605.

4. Rasha Al-Lamee, Alfonso Ielasi, AzeemLatib, et al. Incidence, Predictors, Management, Immediate and Long-Term Outcomes Following Grade III Coronary Perforation. J Am CollCardiolIntv. 2011;4(1):87-95. doi:10.1016/j.jcin.2010.08.026

5. Javaid A., Buch A.N., Satler L.F. Management and outcomes of coronary artery perforation during percutaneous coronary intervention. Am J Cardiol.98 2006:911-914.

6. Shimony A., Zahger D., Van Straten M. Incidence, risk factors, management and outcomes of coronary artery perforation during percutaneous coronary intervention. Am J Cardiol.104 2009:1674-1677. 